\title{
BAGAIMANA KONSUMEN KOSMETIK MEMERHATIKAN BEAUTY VLOGGER DAN PENGARUHNYA TERHADAP NIAT BELI
}

\author{
Lika Alda Septiani \\ Universitas Negeri Surabaya \\ septianlikaalda@gmail.com
}

\begin{abstract}
This study aims to determine the effect of physical attractiveness, attitude homophily, social attractiveness, credibility, and parasocial interaction on cosmetics purchase intention based on the TasyaFarasya review. TasyaFarasya is one of the beauty vloggers on YouTube and Instagram. This study uses a quantitative approach. The sampling technique used is non-probability sampling which is judgmental sampling. In this study, the respondents are women; they knew TasyaFarasya as a beauty vlogger; the age is around 17-35 years and watched content from TasyaFarasya. The number of samples is 200 respondents. The data was processed using PLS-SEM with SmartPLS software version 3.3.3. The findings of this study indicate that physical attractiveness, homophily attitudes have a significant effect on credibility. While physical attractiveness and social attractiveness significantly affect parasocial interactions, homophily attitudes do not affect parasocial interactions. Credibility does not affect purchase intention, but parasocial interaction has a significant effect on purchase intention. Further research can add information and building motive variables. It is also interesting to see further how the interaction between vlogger viewers.
\end{abstract}

Keywords: beauty vlogger; cosmetics; online review; purchase intention; social media.

\section{PENDAHULUAN}

Perkembangan teknologi informasi internet mendorong pertumbuhan media sosial sehingga mengubah cara komunikasi. Media sosial merupakan komunitas interaktif yang didukung internet dan teknologi informasi dan telekomunikasi (Zhou \& Wang, 2014). Terdapat berbagai jenis platform media sosial yang digunakan di Indonesia, antara lain YouTube, WhatsApp, Facebook, Instagram, dan Twitter. YouTube merupakan platform media sosial yang paling aktif digunakan dengan presentasi $88 \%$, kemudian WhatsApp 84\%, Facebook 82\%, Instagram 79\%, dan Twitter dengan 56\% (wearesocial.com, 2020).

YouTube merupakan video sharing website untuk membuat dan mengunggah video agar dapat disaksikan penonton secara gratis. Selain itu, YouTube memiliki fitur like, comment, share dan subscribe (Freeman \& Chapman, 2007). Penonton YouTube mencapai 63 juta penonton setiap bulanya pada tahun 2019. Peningkatan jumlah penonton mencapai 93 juta penonton setiap bulannya pada tahun 2020, peningkatan tersebut disebabkan oleh kreatifitas content creator sehingga menambah jumlah subscriber. Ada 600 saluran YouTube di Indonesia yang memiliki satu juta subcriber dengan berbagai kategori (Tesalonika, 2020). Vlog merupakan kategori umum yang digunakan di saluran YouTube. Vlog (video blog) diproduksi oleh content creator dengan pengeditan agar hasilnya lebih menarik. Content creator YouTube disebut sebagai entrepreneurial vloggers. Vlogger memiliki tujuan komersial untuk memperoleh pendapatan dari iklan YouTube. YouTube memiliki influencer yang berperan untuk mendukung produk atau mengulas produk (Nandagiri \& Philip, 2018).

Instagram memiliki berbagai fitur seperti filter, Instagram Story, IGTV, live, comment, explore, dan share (Sendari, 2019). Pengguna Instagram dapat memposting konten yang berupa foto atau video disertai caption (Sokolova \& Kefi, 2020). Instagram semakin populer di kalangan generasi millenial dan generai Z (Copeland \& Zhao, 2020). Selain itu, Instagram adalah platform media sosial yang cepat dalam mengirimkan pesan visual singkat ke target atau pengikut (Copeland \& Zhao, 2020). Instagram mengalami pertumbuhan pengguna tercepat di mana pengguna Instagram berbagi foto ke sesama pengguna. Pengguna Instagram di Indonesia 82,32 juta pada Januari tahun 2021 
(napoleoncat.com, 2021). Individu cenderung berselancar di Instagram dalam waktu yang lama daripada situs serupa lainnya (Djafarova \& Rushworth, 2017).

Konten dalam YouTube dan Instagram yang dibuat oleh orang-orang yang disebut content creator (Lutfia, 2021). Salah satu cara penyajian informasi atau konten yang paling populer di media sosial termasuk YouTube dan Instagram adalah melalui video blogging atau vlogging yang memanfaatkan foto dan video untuk membuat konten web. Vlog sering diunggah oleh vloggers di platform video seperti YouTube (Chen \& Dermawan, 2020). Seorang vlogger dapat menyampaikan pesan, opini, dan review kepada audiens yang tidak dapat memberikan umpan balik langsung pada saat yang bersamaan. Selanjutnya, vlogger dapat memberikan referensi bagi pengikutnya yang dianggap sebagai pemimpin opini (Ramadanty et al., 2020). Ada beberapa kategori vlog yang di upload oleh vlogger yaitu daily vlog, travel vlog, food vlog, relationship vlog, beauty vlog, kids vlog, dan cinematic vlog (Hestianingsih, 2019; Tysara, 2021).

Beauty vlog merupakan kategori vlog yang paling banyak ditonton oleh perempuan (Jerslev, 2016). Perempuan merupakan konsumen terbesar produk kosmetik. Perempuan menggunakan kosmetik untuk penampilan dan meningkatkan kepercayaan diri (Briliana \& Mursito, 2017). Alasan menonton review yaitu perempuan tidak akan sembarangan dalam memilih produk kecantikan. Konsumen kosmetik akan memikirkan dengan matang kemungkinan kesesuaian produk kosmetik dengan kondisi kulitnya. Apabila perempuan telah merasa cocok dengan sebuah produk kosmetik maka mereka akan enggan untuk beralih ke produk kosmetik lain (Apriliani et al., 2020). Alasan lainnya karena mayoritas beauty vlogger secara objektif mengulas berbagai produk yang telah mereka gunakan, memberikan informasi positif atau negatif kepada konsumen (Chen \& Dermawan, 2020).

Influencer di bidang kecantikan disebut dengan beauty vlogger (Safira et al., 2019). Konten beauty vlogger berpusat pada topik terkait dengan kecantikan yang memiliki empat kategori video yaitu haul, first impression, monthly favourite dan tutorial (Berryman \& Kavka, 2017). Beauty vlogger Indonesia yang memiliki jumlah subscriber terbanyak yaitu Tasya Farasya dengan 3,32 juta subscriber, Suhay Salim dengan 1,31 juta subscriber, Rachel Goddard dengan 2,55 juta subscriber. Tasya Farasya mulai menjadi beuaty vlogger pada 2017 dan mendapatkan Rp 119,49 juta sampai Rp 418,2 juta setiap bulannya (Nasuha, 2020). Penghasilannya di dominasi dari review hingga endorse. Tasya Farasya rutin mengunggah video tentang kosmetik di YouTubenya, hingga saat ini jumlah subscriber YouTube Tasya Farasya mencapai 3,71 juta (Lova, 2020). Tasya Farasya juga memiliki 4,5 juta followers (instagram.com, 2021).

Kehadiran beauty vlogger memudahkan konsumen untuk mengetahui merek atau produk yang akan digunakan. Kemudahan yang didapatkan yaitu insight ataupun review beauty vlogger terkait detail informasi produk, kelebihan dan kekurangan produk, serta kesan setelah mencoba produk tersebut. Hal tersebut menjadikan kehadiran beauty vlogger semakin diminati khalayak umum terutama pengguna YouTube dan Instagram untuk mengenalkan produk. Beauty vlogger akan secara langsung memengaruhi niat beli produk. Tujuannya adalah mempersuasi dan mengedukasi secara langsung terkait produk kecantikan (Agustiara et al., 2019).

Niat beli merupakan suatu perihal yang mewakili konsumen yang memiliki kemungkinan, akan rencana, atau bersedia membeli produk dan jasa di masa yang akan datang (Schiffman \& Kanuk, 2007). Study pada penelitian menunjukkan bahwa niat beli konsumen dipengaruhi oleh parasocial interaction dan kredibilitas influencer (Sokolova \& Kefi, 2020). Hal tersebut sejalan dengan Argyris et al., (2020), Nam \& Dan, (2018), Pick, (2020), dan Reinikainen et al., (2020) yang menunjukkan bahwa kredibilitas berpengaruh signifikan terhadap niat beli. Namun, dalam penelitian lainnya kredibilitas tidak berpengaruh signifikan terhadap niat beli (Lim et al., 2017). Penelitian Kim (2020), Purnamaningsih \& Rizkalla (2020) menunjukkan bahwa parasocial interaction berpengaruh signifikan positif terhadap niat beli. 
Lika Alda Septiani. Bagaimana Konsumen Kosmetik Memerhatikan Beauty Vlogger dan Pengaruhnya terhadap Niat Beli

Parasocial interaction terjadi pada media tradisional dan media sosial. Media sosial dapat digunakan oleh konsumen untuk berkomunikasi secara langsung dengan seseorang seolah teman dekat dan dapat memberikan komentar terkait kehidupanya (Liu et al., 2019). Di sektor pemasaran, Parasocial interaction sebagai hubungan timbal balik imajiner antara audiens dan orang tertentu. Hubungan tersebut terjalin jika penonton terus mengikuti aktivitas persona di media (Purnamaningsih \& Rizkalla, 2020). Parasocial interaction dibentuk oleh physical attractiveness, attitude homophily, dan social attractiveness (Sokolova \& Kefi, 2020). Kredibilitas mengacu pada karakteristik positif seorang komunikator yang dapat memengaruhi akseptabilitas pesan. (Rahmi et al., 2017). Keahlian merupakan salah satu faktor utama kredibilitas, bersama dengan kepercayaan, dan good will. Kredibilitas dibentuk oleh physical attractiveness, attitude homophily, dan social attractiveness (Sokolova \& Kefi, 2020).

Ketertarikan pada sesorang di media sosial dapat meningkatkan interaksi dan penayangan ulang dari konten yang dimiliki oleh seseorang. Orang dikatakan menarik secara fisik apabila penampilan mereka menyenangkan secara estetika. Orang yang menarik secara fisik dianggap memiliki ciri kepribadian yang lebih disukai seperti kemampuan intelektual, sosial dan integrasi (Liu et al., 2019). Kepribadian yang positif dan menyenangkan dari beauty vlogger dapat membuat penonton menyukai dan menghabiskan lebih banyak waktu untuk menonton setiap konten yang mereka upload di saluran YouTubenya (Purnamaningsih \& Rizkalla, 2020). Sokolova \& Kefi (2020) dan Hong et al., (2020) menemukan bahwa physical attarctiveness berpengaruh signifikan positif terhadap kredibilitas. Selain itu, physical attarctiveness juga berpengaruh signifikan positif terhadap parasocial interaction (Lee \& Watkins, 2016; Liu et al., 2019; Putri \& Astuti, 2019; Sokolova \& Kefi, 2020).

Attitude homophily terjadi ketika seseorang merasa bahwa mereka memiliki kesamaan dengan orang lain, seperti keinginan dan minat yang sama dalam bidang tertentu dan berpotensi terjadi interaksi. Misalnya, jika seorang subscriber merasa memiliki kesamaan dengan beauty vlogger dalam hal menjaga penampilan fisik yang baik atau dalam memilih produk kecantikan yang tepat, hal ini akan mendorongnya untuk ingin menonton lebih banyak review produk kecantikannya dan melakukan interaksi melalui komentar (Purnamaningsih \& Rizkalla, 2020). Attitude homophily juga berpengaruh signifikan postif terhadap kredibilitas (Frederick et al., 2016; Sokolova \& Kefi, 2020; Xiao et al., 2018). Menurut Sokolova \& Kefi (2020), Arviansyah et al., (2018), Purnamaningsih \& Rizkalla (2020), attitude homophily berpengaruh signifikan positif terhadap parasocial interaction.

Social attractiveness diartikan sebagai kemungkinan untuk berteman atau memilih figur media sebagai sosial atau mitra kerja. Beauty vlogger yang menarik dapat mengubah sikap penonton dan cenderung memengaruhi audiens (Sokolova \& Kefi, 2020). Seseorang cenderung memandang orang yang mirip dengan dirinya sebagai orang yang menarik secara sosial dan mengembangkan hubungan dengan orang yang mereka sukai. Vlog yang komunikatif dan responsif di media sosial menciptakan ilusi kepada pengguna media sosial bahwa mereka berperilaku seolah-olah berada di lingkaran teman sebayanya. Semakin pengguna media sosial melihat beberapa kesamaan dengan orang lain di media sosial, maka mereka akan menyukainya (Liu et al., 2019). Penelitian menunjukkan bahwa social attractiveness berpengaruh signifikan positif terhadap parasocial interaction (Arviansyah et al., 2018; Lee \& Watkins, 2016; Sokolova \& kefi 2020) sedangkan menurut Purnamaningsih \& Rizkalla (2020), social attarctiveness tidak berpengaruh signifikan terhadap parasocial interaction.

Berdasarkan latar belakang tersebut penelitian ini bertujuan untuk mengetahui bagaimana konsumen kosmetik memerhatikan beauty vlogger dan pengaruhnya terhadap niat beli.

\section{KAJIAN PUSTAKA DAN PENGEMBANGAN HIPOTESIS}

\section{Komunikasi dan Persuasi}

Model komunikasi dua langkah memperkenalkan opinion leader dan opinion former. Opinion former adalah individu yang dapat memberikan pengaruh pada kehidupan individu, misalnya penyiar, jurnalis, politisi, ilmuwan, analis, atau seseorang yang dapat dipercaya untuk memberikan nasehat yang baik. Alur komunikasi dua langkah menjelaskan tahapan pengaruh penyebaran informasi 
melalui media massa kepada khalayak umum. Model ini dapat mengetahui penyebaran dan pengaruh informasi yang disampaikan melalui media massa kepada khalayak umum tidak terjadi secara langsung melainkan melalui opinion leader. Proses penyebaran informasi melalui media massa terjadi dalam dua tahap. Pertama, opinion leader menerima informasi dari media massa. Kemudian, opinion leader dapat meneruskan informasi atau komentar dan pendapatnya kepada sejumlah orang yang menjadi pengikut. Semakin terkenal opinion leader maka bisa menjadi pembuat tren Opinion leader merupakan individu yang memiliki kemampuan untuk memengaruhi, tetapi bukan ahli formal. Mereka tidak langsung memberi nasehat, tapi konsumen cenderung mengikuti pendapat mereka (Egan, 2014:39). Persuasi merujuk pada elaboration model of persuasion (ELM) yang berkaiatan dengan motivasi dan kemampuan menyampaikan pesan untuk memengaruhi sikap ,niat, dan keyakianan penerima (Bhattacherjee \& Sanford, 2016).

\section{Influencer}

Influencer merupakan content creator yang mengumpulkan basis pengikut yang kuat melalui blog, vlogging, atau membuat konten pendek di media sosial seperti Instagram dan SnapChat. Influencer memberikan wawasan kepada pengikut mereka tentang diri influencer, kehidupan sehari-hari, pengalaman, dan pendapat mereka. Keterlibatan influencer dalam kegiatan menawarkan produk untuk menguji produk atau review, menyelenggarakan acara eksklusif, atau endorse bertujuan untuk merangsang influencer untuk mendukung produk dari perusahaan. Cara ini dapat membangun citra produk di antara basis pengikut influencer yang sangat besar. Berbeda dengan selebriti, influencer diyakini dapat diakses, dipercaya, intim dan mudah dihubungkan saat mereka berbagi aspek kehidupan pribadi, dan dapat berinteraksi. Influencer memiliki beberapa jenis yaitu influencer selebriti, megainfluencer, makroinfliencer, microinfluencer, dan nanoinfluencer. Jenis influencer tersebut berdasarkan jumlah pengikut dan asal influencer tersebut, seperti selebriti atau bukan selebriti (Veirman et al., 2017).

\section{Niat Beli}

Niat beli terletak pada tahap pra pembelian evaluasi pra pembelian konsumen. Pada tahap evaluasi oleh konsumen, konsumen akan mengumpulkan berbagai informasi mengenai produk yang kemudian akan dievaluasi beradasarkan kriteria yang telah ditetapkan konsumen. Evaluasi dilakukan berdasarkan subjektfitas konsumen. Konsumen akan mengganggap produk tersebut baik apabila memenuhi kriteria dari konsumen. Niat beli produk akan terjadi apabila ada kesesuaian antara kriteria konsumen dengan produk (Engel et al., 1995:201). Fishbein \& Ajzen (2001) menyatakan bahwa niat beli merupakan situasi di mana individu sebelum melakukan suatu aksi yang digunakan sebagai dasar untuk memprediksi sikap atau aksi tersebut. Sokolova \& Kefi (2020), Picky (2020) dan Putri \& Astuti (2021), menyatakan bahwa indikator niat beli beli yaitu konsumen bersedia mencoba produk dan konsumen akan membeli produk.

\section{Parasocial Interaction}

Parasocial interaction mengacu pada sejauh mana pengguna media memandang persona media sebagai mitra sosial yang intim. Dalam parasocial interaction, audiens menganggap persona media sebagai teman, konselor, penghibur, atau panutan. Parasocial Interaction berkembang secara sukarela dan dengan cara yang mirip dengan bagaimana persahabatan terjadi. Pengguna media yang terlibat dalam parasocial interaction yang luas cenderung menganggap diri mereka memiliki sejumlah kesamaan dengan persona media dan ketidakpastian yang rendah dalam interaksi mereka (Liu et al., 2019). Parasocial interaction didefinisikan sebagai interaksi satu sisi imajiner antara kepribadian media dan penggemar. Parasocial interaction yang berkembang dengan vlogger memengaruhi pembelian. Vlogger layaknya selebriti yang memiliki banyak penggemar. Beberapa vlogger memiliki jutaan penggemar, dan mereka dapat memengaruhi penggemar melalui parasocial interaction. Parasocial interaction juga menunjukkan bahwa seorang penggemar dapat mengembangkan hubungan yang dipandang sebagai teman sejati. Parasocial interaction dapat terjadi ketika penonton tidak secara fisik berinteraksi dengan vlogger (Arviansyah et al., 2018). Menurut Sokolova \& Kefi (2020), parasocial interaction merupakan hubungan antara penonton dengan influencer yang terjadi di media tradisional dan media sosial. 
Lika Alda Septiani. Bagaimana Konsumen Kosmetik Memerhatikan Beauty Vlogger dan Pengaruhnya terhadap Niat Beli

\section{Kredibilitas}

Kredibilitas merupakan tingkat kepercayaan yang dirasakan oleh penonton dan keandalan dari influencer. Faktor utama kredibilitas seorang influencer yaitu memiliki keahlian, pengetahuan tentang produk, dan dapat dipercaya sebagai sumber informasi (Sokolova \& Kefi, 2020). Kredibilitas mengacu pada karakteristik positif seorang komunikator yang dapat memengaruhi akseptabilitas pesan. Kredibilitas yang dirasakan dapat meningkatkan kekuatan persuasif dari sebuah pesan, yang mengarah pada perubahan sikap (Rahmi et al., 2017). Kredibilitas juga dianggap sebagai opini terhadap realitas review, bahkan review tersebut dapat memengaruhi sikap konsumen (Chakraborty, 2019).

\section{Physical Attractiveness}

Physical attractiveness menggambarkan betapa menarik atau menyenangkan penampilan fisik dan keindahan estetika individu (Sokolova \& Kefi, 2020). Physical attractiveness mengacu pada vlogger sebagai sosok menarik yang memengaruhi penonton untuk lebih sering menonton vlog mereka. Sebagai contoh dari physical attractiveness dari vlogger yaitu cara mereka berpakaian, penampilan yang menarik dan rapi di depan kamera (Razak \& Zulkifly, 2020). Menurut Lee \& Watkins (2016) physical attractiveness merupakan bagian dari parasocial interaction yang dapat memengaruhi konsumen online. Sokolova \& Kefi (2020), Lee \& Watkins (2016), Liu et al, (2019), dan Putri \& Astuti (2021) menyebutkan bahwa physical attractiveness dapat dilihat dari penampilan yang menarik dan kecantikan beauty vlogger.

\section{Attitude Homophily}

Attitude homophily didefinisikan sebagai sejauh mana orang cenderung terikat dengan orang lain yang serupa dan dianggap sebagai faktor penjelasan komunikasi interpersonal dan pola hubungan berbasis pengaruh, terutama dalam studi jejaring sosial (Sokolova \& Kefi, 2020). Attitude homophily merupakan pemikiran atau perasaan terhadap sesuatu atau seseorang, atau juga cara berperilaku yang disebabkan oleh keadaan tertentu, dan memiliki cenderung untuk menjalin persahabatan antara orangorang yang serupa dalam beberapa hal tertentu (Razak \& Zulkifly, 2020). Menurut Sokolova \& Kefi (2020), Lee \& Watkins (2016), dan Purnamaningsih \& Rizkalla (2020) menyatakan bahwa keserupaan yang dimiliki dapat berupa menganut nilai yang sama dan pola pikir.

\section{Social Attractiveness}

Social attractiveness mengacu pada keserupaan persona media dan mempertimbangkan persona media sebagai teman yang layak (Liu et al., 2019). Menurut Sokolova \& Kefi (2020), social attractiveness mengacu pada kesukaan pembicara. Pembicara yang menarik dapat mengubah sikap penonton. Pesan yang sama dapat disampaikan dengan cara yang lebih menarik yang memiliki social attractiveness tinggi. Seseorang cenderung memandang orang yang mirip dengan dirinya sendiri sebagai orang yang menarik secara sosial dan mengembangkan hubungan dengan orang yang mereka sukai. Menurut Sokolova \& Kefi (2020), Lee \& Watkins (2016), dan Liu et al, (2019) menyatakan bahwa social attractiveness dapat dilihat dari perilaku, pemikiran, dan ide yang sama serta keinginan untuk berteman.

\section{Hubungan antar Variabel}

Physical attractiveness adalah sifat seseorang yang paling terlihat dan paling mudah diketahui. Physical attractiveness juga merupakan isyarat informasional yang konsisten dan sering digunakan. Fakta-fakta ini menjadi alasan mengapa physical attractiveness begitu penting dan memiliki pengaruh yang besar dalam kehidupan di masyarakat saat ini. Physical attractiveness tertanam kuat dalam persepsi seseorang. Hubungan tersebut dengan mudah dipahami ketika persepsi seseorang diartikan sebagai proses di mana seseorang memandang dan berpikir tentang orang lain, karakteristiknya, kualitasnya, dan sifat (Lee \& Watkins, 2016). Physical attractiveness mencerminkan betapa menarikny fisik dari beauty vlogger dan keindahan yang estetik yang muncul dari diri beauty vlogger (Lee \& Watkins, 2016; Liu et al., 2019; Sokolova \& Kefi, 2020). Physical attractiveness berpengaruh signifikan positif terhadap kredibiltas (Hong et al., 2019; Sokolova \& Kefi, 2020).

H1: Physical attractiveness berpengaruh positif terhadap kredibilitas. 
Menurut Sokolova \& Kefi (2020), physical attractiveness berpengaruh signifikan positif terhadap parasocial interaction. Physical attractiveness berhubungan erat dengan parasocial intearaction. Penelitian lain juga menyebutkan bahwa physical attractiveness berpengaruh signifikan positif terhadap parasocial interaction. Influencer kecantikan atau beauty vlogger yang memiliki physical attractiveness yang tinggi cenderung mengakibatkan seorang penonton berkeinginan untuk berinteraksi secara langsung maupun tidak langsung dengan beauty vlogger (Arviansyah et al., 2018; Lee \& Watkins, 2016; Purnamaningsih \& Rizkalla, 2020). Penelitian terdahulu membuktikan bahwa physical attractiveness berpengaruh signifikan positif terhadap parasocial interaction (Lee \& Watkins, 2016; Liu et al., 2019; Putri \& Astuti, 2019).

\section{H2: Physical attractiveness berpengaruh positif terhadap parasocial interaction.}

Menurut Sokolova \& Kefi (2020), attitude homophily merupakan salah satu faktor penentu kredibilitas. Attitude homophily berpengaruh signifikan positif terhadap kredibilitas. Attitude homophily adalah sejauh mana individu berinteraksi dengan orang lain berdasarkan kesamaan. Kesamaan tersebut dapat obyektif atau subyektif. Subjektif ketika menyangkut persepsi sesorang tentang seberapa mirip dengan influencer atau beauty vlogger. Attitude homophily juga bisa menjadi anteseden atau hasil komunikasi (Eyal \& Rubin, 2010). Penelitian lain meyebutkan bahwa attitude homophily beprengaruh signifikan positif terhadap kredibilitas (Frederick et al., 2016; Xiao et al., 2018).

H3: Attitude homophily berpengaruh positif terhadap kredibilitas.

Menurut Sokolova \& Kefi (2020), atttude homophily berpengaruh signifikan positif terhadap parasocial interaction. Semakin individu terikat dengan influencer kecantikan atau beauty vlogger, maka dapat menimbulkan komunikasi interpersonal dan pola hubungan berbasis pengaruh dalam media sosial (Sokolova \& Kefi, 2020). Penelitian lainnya juga menyebutkan bahwa attitude homophily berpengaruh signifikan positif terhadap parasocial interaction (Arviansyah et al., 2018; Purnamaningsih \& Rizkalla, 2020).

\section{H4: Attitude homophily berpengaruh positif terhadap parasocial interaction.}

Social attractiveness mengacu pada keserupaan persona media dan mempertimbangkan persona media sebagai teman yang layak atau kemungkinan untuk berteman atau memilih figur media sebagai sosial atau mitra kerja (Sokolova \& Kefi, 2020). Social Attractiveness berpengaruh signifikan positif terhadap parasocial interaction (Sokolova \& Kefi, 2020). Penelitian lain juga menyebutkan bahwa social attractiveness berpengaruh signifikan positif terhadap parasocial interaction (Arviansyah et al., 2018; Lee \& Watkins, 2016). Namun, penelitian lain menyatakan bahwa social attractiveness tidak berpengaruh signifikan terhadap parasocial interaction (Purnamaningsih \& Rizkalla, 2020).

H5: Social attractiveness berpengaruh positif terhadap parasocial interaction.

Kredibilitas influencer kecantikan atau beauty vlogger dalam menyampaikan pesan kepada penonton dapat memengaruhi niat beli konsumen atas produk yang di-review oleh beauty vlogger. Semakin tinggi kredibilitas influencer yang dirasakan oleh konsumen maka akan meningkatkan niat beli konsumen atas suatu produk (Sokolova \& Kefi, 2020). Penelitian lain menyebutkan bahwa kredibilitas influenecer berpengaruh signifikan positif terhadap niat beli (Argyris et al., 2020; Nam \& Dan, 2018; Pick, 2020; Reinikainen et al., 2020). Namun, dalam penelitian lainnya, kredibilitas tidak berpengaruh signifikan terhadap niat beli (Lim et al., 2017).

H6: Kredibilitas berpengaruh positif terhadap niat beli.

Parasocial interaction merujuk pada reaksi pengguna media sosial terhadap influencer sedemikian rupa sehingga pengguna media sosial menganggap influencer sebagai mitra percakapan yang intim. 
Lika Alda Septiani. Bagaimana Konsumen Kosmetik Memerhatikan Beauty Vlogger dan Pengaruhnya terhadap Niat Beli

Rasa memberi dan menerima dalam percakapan sering muncul selama menonton dan meningkat ketika influencer secara fisik berbicara kepada pengguna media sosial (Dibble et al., 2016). Parasocial interaction akan memengaruhi niat beli konsumen (Sokolova \& Kefi, 2020). Selain itu, penelitian lainnya menyebutkan bahwa parasocial interaction berpengaruh signifikan positif terhadap niat beli (Kim, 2020; Purnamaningsih \& Rizkalla, 2020).

H7: Parasocial interaction berpengaruh positif terhadap niat beli.

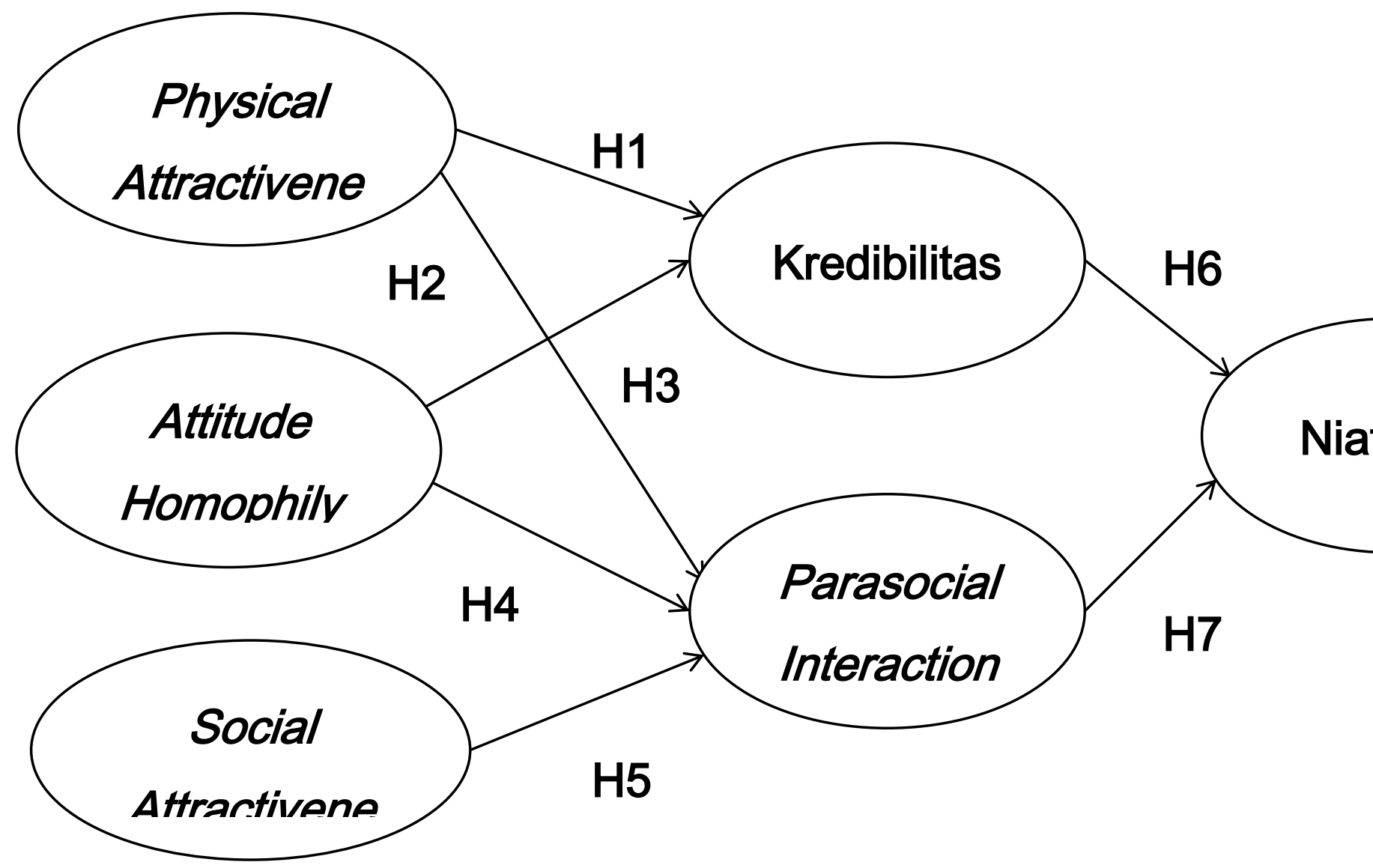

Gambar 1. RANCANGAN PENELITIAN

\section{METODE PENELITIAN}

Penelitian ini menggunakan jenis penelitian dengan klasifikasi penelitian konklusif. Tujuan dari penelitian konklusif adalah menguji hipotesis dan menguji hubungan tertentu. Karakteristik penelitian konklusif yaitu proses penelitian formal dan terstruktur, sampel besar dan representatif dan analisis data bersifat kuantitatif. Rancangan penelitian ini menggunakan rancangan penelitian konklusif dengan jenis penelitian kausal. Penelitian kausal memiliki tujuan untuk mendapatkan bukti mengenai hubungan sebab akibat. Karakteristik responden dalam penelitian ini adalah wanita yang mengenal beauty vlogger Tasya Farasya yang berusia 17-35 tahun dan menonton konten beauty vlogger Tasya Farasya. Teknik yang digunakan untuk mengumpulkan sampel adalah nonprobability sampling dengan teknik judmental sampling. Sampel dalam penelitian ini berjumlah 200 responden. Jenis data yang digunakan adalah jenis data primer. Sumber data primer dari penelitian berupa hasil jawaban responden yang diukur instrumen penelitian berupa pertanyaan tertutup melalui angket penelitian dengan menggunakan skala Likert 1-5. Selain itu, responden juga diminta untuk menjawab pertanyaan terkait profil responden dan beberapa pertanyaan terbuka. Penyebaran angket penelitian dilakukan melalui media sosial WhatsApp, Instagram, dan Twitter. Data yang telah dihasilkan akan 
diolah dengan teknik analisis PLS-SEM dengan software SmartPLS versi 3.3.3. Untuk memperdalam pembahasan, observasi juga dilakukan pada akun YouTube dan Instagram Tasya Farasya.

\section{HASIL DAN PEMBAHASAN}

\section{Profil Responden}

Responden dalam penenlitian ini adalah wanita yang mengenal beauty vlogger Tasya Farasya, berusia 17-35 tahun, dan menonton konten Tasya Farasya. Deskripsi responden dalam penelitian ini berdasakan jenis kelamin, usia, dan frekuensi menonton dapat dijelaskan berdasarkan berikut: responden wanita sejumlah 200 responden atau sebesar 100\%. Karakteristik responden berdasarkan usia yang memiliki usia 17-21 tahun sebanyak 118 responden (59\%), usia 22-25 tahun sebanyak 77 responden (38,5\%), usia 26-30 tahun sebanyak 3 responden (1,5\%), dan usia 31-35 tahun sebanyak 2 reponden $(1 \%)$.

Selanjutnya frekuensi responden menonton Tasya Farasya 1-2 kali dalam satu bulan sebanyak 95 responden (47,5\%), 3-4 kali dalam satu bulan sebanyak 55 responden (27,5\%), 5-6 kali dalam sebulan sebanyak 21 responden $(10,5 \%)$, dan lebih dari 6 kali dalam satu bulan sebanyak 29 responden (14,5\%). Responden mulai menonton Tasya Farasaya kurang dari 6 bulan sebanyak 30 responden (15\%), 1 tahun lalu sebanyak 55 responden (28\%), 2 tahun lalu sebanyak 63 responden (32\%), 3 tahun lalu sebanyak 29 responden (15\%), dan lebih dari 3 tahun lalu sebanyak 23 responden (12\%).

Penelitian juga menanyakan kategori produk dan merek yang dibeli responden setelah melihat review Tasya Farasya, serta frekuensi menonton YouTube dan berselancar di Instagram. Gambar 2 menunjukkan bahwa terdapat dua kategori yang dibeli oleh responden setalah menonton review produk dari Tasya Farasya yaitu kategori produk dan kategori merek. Kategori produk yang dibeli oleh responden yaitu compact powder $1 \%$, blush on $0,5 \%$, cleanser $1 \%$, cushion $2 \%$, concealer $0,5 \%$, facial wash $0,5 \%$, foundation $2 \%$, hair mask $1 \%$, lip product $12 \%$, sheet mask $1 \%$, serum $1 \%$, dan toner 0,5\%. Sedangkan untuk kategori merek yang dibeli yaitu Avoskin 0,5\%, Azarine 1,5\%, Bioderma 0,5\%, Clean and Clear 1\%, Emina 2\%, Focallure 6.5\%, Implora 0,5\%, Luxcrime 0,5\%, Madame Gie 1.5\%, Make Over 2,5\%, Maybelline 2,5\%, Npure 0,5\%, Pixy 2\%, Safi 0,5\%, Some By Mi 0,5\%, Somethinc 0,5\%, Wardah 2\%, dan Whitelab 1,5\%. Hasil tersebut menunjukkan bahwa pembelian kategori produk terbanyak pada lip product sedangkan untuk kategori merek yang banyak dibeli adalah Focallure.

Gambar 3 menunjukkan frekuensi menonton YouTube kurang dari 1 jam setiap harinya sebanyak 56 responden (28\%), lebih dari 1 jam sampai 3 jam sebanyak 103 responden $(51,5 \%)$, lebih dari 3 jam sampai 6 jam sebanyak 28 responden (14\%), lebih dari 6 jam sampai 9 jam sebanyak 8 responden (4\%), dan lebih dari 9 jam sebanyak 5 responden $(2,5 \%)$. Kemudian untuk frekuensi berselancar di Instagram setiap harinya kurang dari 1 jam sebanyak 49 responden $(24,5 \%)$, lebih dari 1 jam sampai 3 jam sebanyak 87 responden (43,5\%), lebih dari 3 jam sampai 6 jam sebanyak 43 responden $(21,5 \%)$, lebih dari 6 jam sampai 9 jam sebanyak 12 responden (6\%), dan lebih dari 9 jam sebanyak 9 responden (4,5\%). Hasilnya menunjukkan bahwa penonton menghabiskan waktu lebih dari 1 jam sampai 3 jam untuk menonton YouTube dan Instagram.

\section{Pengukuran PLS-SEM}

Pemodelan dalam PLS-Path modeling ada dua model yaitu measurement (outer) model dan structural (inner) model. Measurement (outer) model mendefinisakan bagaimana setiap indikator berhubungan dengan variabel latennya. Uji yang dilakukan pada outer model yaitu uji validitas dan reliabilitas. Uji validitas dapat dilihat dari nilai convergent validity dan discriminant validity. Uji reliabilitas dapat 
Lika Alda Septiani. Bagaimana Konsumen Kosmetik Memerhatikan Beauty Vlogger dan Pengaruhnya terhadap Niat Beli

dilihat dari nilai Cronbach's alpha dan composite reliability. Nilai Cronbach's alpha 0,6 sampai 0,9, sementara nilai composite reliability 0,6 sampai 0,7. Sementara structural (inner) model dilakukan untuk menguji hubungan antara konstruk laten. Ada dua uji untuk inner model yaitu $R$ Square dan $Q$ Square. Nilai $R$ Square berkisar antara 0 sampai 1, sedangkan nilai $Q$ Square predictive relevance harus berada diatas nol (Hair et al., 2016)

\section{Measurement Model}

Convergent validity merupakan sejauh mana suatu ukuran berkorelasi secara positif dengan ukuran alternatif dari konstruk yang sama (Hair et al., 2016). Hasil uji convergent validity dapat dilihat dari nilai loading factor. Tabel 1 menunjukkan bahwa semua pernyataan angket memiliki nilai loading factor $>0,5$, hal tersebut menunjukan bahwa semua pernyataan angket yang digunakan valid. Nilai AVE pada tabel 2 menunjukkan variabel physical attractiveness memiliki nilai 0,885, attitude homophily 0,673 , social attractiveness 0,620 , kredibilitas 0,544 , parasocial interaction 0,913 , dan niat beli 0,541 .

\section{Tabel 1. \\ PERNYATAAN ANGKET DAN NILAI LOADING FACTOR}

\begin{tabular}{|c|c|c|}
\hline Butir-Butir Pernyataan & Sumber & Loading \\
\hline \multicolumn{3}{|l|}{ Physical Attractiveness } \\
\hline $\begin{array}{l}\text { Menurut saya, Tasya Farasya adalah beauty vlogger yang } \\
\text { berpenampilan menarik. }\end{array}$ & $\begin{array}{l}\text { Sokolova \& Kefi (2020), Lee \& } \\
\text { Watkins (2016), Liu et al, }\end{array}$ & 0,945 \\
\hline $\begin{array}{l}\text { Menurut saya, Tasya Farasya adalah beauty vlogger yang } \\
\text { cantik }\end{array}$ & $\begin{array}{l}\text { (2019), dan Putri \& Astuti } \\
\text { (2021) }\end{array}$ & 0,958 \\
\hline \multicolumn{3}{|l|}{ Attitude Homophily } \\
\hline $\begin{array}{l}\text { Tasya Farasya selalu mereview produk kosmetik yang } \\
\text { memiliki izin BPOM sesuai dengan standar kosmetik yang } \\
\text { sava gunakan }\end{array}$ & $\begin{array}{l}\text { Sokolova \& Kefi (2020), Lee \& } \\
\text { Watkins (2016), dan }\end{array}$ & 0,745 \\
\hline $\begin{array}{l}\text { Saya gunakan } \\
\text { Saya merasa memiliki pola pikir yang sama dengan Tasya } \\
\text { Farasya }\end{array}$ & $\begin{array}{l}\text { Purnamaningsih \& Rizkalla } \\
\text { (2020) }\end{array}$ & 0,89 \\
\hline \multicolumn{3}{|l|}{ Social Attractiveness } \\
\hline $\begin{array}{l}\text { Saya merasa Tasya Farasya memiliki perilaku yang sama } \\
\text { dengan saya. }\end{array}$ & $\begin{array}{l}\text { Sokolova \& Kefi (2020), Lee \& } \\
\text { Watkins (2016), dan Liu et al, }\end{array}$ & 0,826 \\
\hline $\begin{array}{l}\text { Saya merasa Tasya Farasya memiliki pemikiran yang mirip } \\
\text { dengan saya. }\end{array}$ & (2019 & 0,834 \\
\hline $\begin{array}{l}\text { Saya merasa Tasya Farasya memiliki ide yang mirip dengan } \\
\text { saya. }\end{array}$ & & 0,782 \\
\hline $\begin{array}{l}\text { saya merasa menjadi teman Tasya Farasya adalah hal yang } \\
\text { menyenangkan }\end{array}$ & & 0,701 \\
\hline \multicolumn{3}{|l|}{ Kredibilitas } \\
\hline Menurut saya, Tasya F & Sokolova \& Kefi (2020), Agusti & 0,547 \\
\hline Menurut saya, Tasya Farasya dapat dipercaya. & \& Widyanto (2020), dan Picky & 0,704 \\
\hline Menurut saya, Tasya Farasya memiliki integritas y & (2020) & 0,762 \\
\hline , Tasya Farasya peduli dengan subscribernya. & & 0,704 \\
\hline $\begin{array}{l}\text { Menurut saya, Tasya Farasya merupakan beauty vlogger } \\
\text { yang akrab dengan subscribernya. }\end{array}$ & & 0,779 \\
\hline Jalu memnerbarui konten YouTuhenya & & 0,717 \\
\hline followernya & & 0,854 \\
\hline $\begin{array}{l}\text { Menurut saya, Tasya Farasya merupakan beauty vlogger } \\
\text { yang akrab dengan followernya. }\end{array}$ & & 0,831 \\
\hline $\begin{array}{l}\text { Tasya Farasya selalu memperbarui postingan Instagramnya. } \\
\text { Parasocial Interaction }\end{array}$ & & 0,694 \\
\hline $\begin{array}{l}\text { Saya menantikan video Tasya Farasya di channel } \\
\text { YouTubenya. }\end{array}$ & $\begin{array}{l}\text { Sokolova \& Kefi (2020), Lee \& } \\
\text { Watkins (2016), Liu et al, }\end{array}$ & 0,808 \\
\hline $\begin{array}{l}\text { Saya menantikan Tasya Farasya live di channel YouTubenya. } \\
\text { Saya menantikan komentar Tasya Farasya di channel } \\
\text { YouTubenya. }\end{array}$ & $\begin{array}{l}\text { (2019), dan Putri \& Astuti } \\
\text { (2021) }\end{array}$ & $\begin{array}{l}0,761 \\
0,768\end{array}$ \\
\hline Saya menantikan video Tasya Farasya di chan & & 0,741 \\
\hline
\end{tabular}




\begin{tabular}{|c|c|c|}
\hline Butir-Butir Pernyataan & Sumber & Loading \\
\hline lainnya. & & \\
\hline $\begin{array}{l}\text { Saya menantikan Tasya Farasya live di channel YouTube } \\
\text { lainnya. }\end{array}$ & & 0,759 \\
\hline $\begin{array}{l}\text { Saya menantikan postingan Tasya Farasya di akun } \\
\text { Instagramnya. }\end{array}$ & & 0,77 \\
\hline $\begin{array}{l}\text { Saya menantikan komentar Tasya Farasya di akun } \\
\text { Instagramnya. }\end{array}$ & & 0,809 \\
\hline Saya akan mensubscribe channel YouTube Tasya Farasya. & & 0,599 \\
\hline saya akan mengikuti akun Instagram Taysa Farasya & & 0,681 \\
\hline $\begin{array}{l}\text { Saya akan berinteraksi dengan Tasya Farasya di channel } \\
\text { YouTubenya }\end{array}$ & & 0,779 \\
\hline $\begin{array}{l}\text { Saya akan berinteraksi dengan Tasya Farasya di akun } \\
\text { Instagramnya }\end{array}$ & & 0,797 \\
\hline $\begin{array}{l}\text { Tasya Farasya membuat saya nyaman seolah sedang bersama } \\
\text { teman. }\end{array}$ & & 0,77 \\
\hline Saya ingin bertemu langsung dengan Tasya Farasya & & 0,642 \\
\hline $\begin{array}{l}\text { Tasya Farasya membantu saya untuk memutuskan tentang } \\
\text { merek tertentu }\end{array}$ & & 0,552 \\
\hline Niat Beli & & \\
\hline Saya akan mencoba merek yang di-review Tasya Farasya & Sokolova \& Kefi (2020), Picky & 0,945 \\
\hline Saya akan membeli merek yang di-review Tasya Farasya & $\begin{array}{l}(2020) \text { dan Putri \& Astuti } \\
(2021)\end{array}$ & 0,937 \\
\hline
\end{tabular}

Sumber: Data diolah

Tabel 2. CONSTRUCT RELIABILITY

\begin{tabular}{lccc}
\hline & Cronbach's Alpha & Composite Reliability & AVE \\
\hline Attitude Homophily & 0,627 & 0,803 & 0,673 \\
Kredibilitas & 0,892 & 0,914 & 0,544 \\
Parasocial Interaction & 0,904 & 0,954 & 0,913 \\
Phisycal Attractiveness & 0,871 & 0,939 & 0,885 \\
Niat Beli & 0,933 & 0,942 & 0,541 \\
Social Attractiveness & 0,797 & 0,867 & 0,620 \\
\hline
\end{tabular}

Sumber: Output SmartPLS 3.3.3, data diolah

Uji validitas dilihat dari nilai discriminnat validity. Discriminnat validity bertujuan mengetahui sejauh mana suatu konstruk berbeda dari konstruk lain menurut standar empiris (Hair et al., 2016). Menetapkan discriminnat validity menyiratkan bahwa sebuah konstruk itu unik dan menangkap fenomena yang tidak direpresentasikan oleh konstruk lain dalam model. Hasil discriminant validity juga dapat dilihat dari nilai Fornell-Larcker criterion. Nilai Fornell-Larcker criterion variabel physical attractiveness sebesar 0,955, attitude homophily sebesar 0,820, social attractiveness sebesar 0,788, kredibilitas sebesar 0,738, parasocial interaction sebesar 0,731, dan niat beli sebesar 0,941.

Nilai composite reliability dan Cronbach's alpha dapat dilihat di tabel 2. Variabel attitude homophily dapat dimengerti memiliki nilai cronbach alpha sebesar 0,627, kredibilitas sebesar 0,892, parasocial interaction sebesar 0,904, physical attractivenes sebesar 0,871, niat beli sebesar 0,933, dan social attractiveness sebesar 0,797. Nilai composite reliability juga dapat dilihat di tabel 2 . Nilai composite reliability untuk variabel attitude homophily dapat dimengerti sebesar 0,803, kredibilitas sebesar 0,914, parasocial interaction sebesar 0,954, physical attractivenes sebesar 0,939, niat beli sebesar 0,942 , dan social attractiveness sebesar 0,867. Nilai Conbach's alpha dan composite reliability menunjukkan bahwa variabel tersebut reliable.

\section{Structural Model}


Lika Alda Septiani. Bagaimana Konsumen Kosmetik Memerhatikan Beauty Vlogger dan Pengaruhnya terhadap Niat Beli

Nilai $R$ Square untuk variabel kredibilitas sebesar 0,286 (28,6\%), parasocial interaction sebesar $0,328(32,8 \%)$, dan niat beli sebesar $0,437(43,7 \%)$. Hal ini menunjukkan besar pengaruh physical attractiveness dan attitude homophily terhadap kredibilitas sebesar 28,6\% sedangkan 71,4\% dipengaruhi oleh variabel independen lain yang tidak terdapat pada penelitian ini seperti variabel trustworthiness, social influence, argument quality, dan information involvement (Xiao et al., 2018). Besar pengaruh physical attractiveness, attitude homophily, dan social attractiveness terhadap parasocial interaction sebesar $32,8 \%$, sedangkan $67,2 \%$ lainnya dipengaruhi oleh variabel lain yang tidak terdapat pada penelitian ini seperti variabel entertainment motive relationship, building motive, dan time spent on the media (Liu et al., 2019). Kemudian besar pengaruh kredibilitas dan parasocial interaction terhadap niat beli sebesar $43,7 \%$ sedangkan 56,3\% dipengaruhi oleh variabel lain seperti citra merek (Jalilvand \& Samiei, 2012). Kredibilitas memiliki nilai $Q$ Square sebesar 0,133 (13,3\%) parasocial interaction sebesar 0,224 (22,4\%), dan niat beli sebesar 0,266 (26,6\%).

\section{Uji Hipotesis}

Hipotesis dinyatakan terbukti signifikan apabila memiliki t value $\leq 1,65$ dan $\mathrm{p}$ value $<0,001$, $\mathrm{p}$ value $<$ 0,1, dan p value < 0,05 (Hair et al., 2016). Tabel 3 menunjukkan bahwa H1, H2, H3, H5, dan H7 terbukti dalam penelitian ini, sedangkan $\mathrm{H} 4$ dan $\mathrm{H} 6$ tidak terbukti.

Tabel 3.

UJI HIPOTESIS

\begin{tabular}{lllll}
\hline & \multicolumn{1}{c}{ Hipotesis } & t value & p value & \multicolumn{1}{c}{ Keterangan } \\
\hline H1 & Physical Attractiveness - Kredibilitas & 1,859 & $0,032^{*}$ & Terbukti \\
H2 & Physical attractiveness - Parasocial Interaction & 2,000 & $0,023^{*}$ & Terbukti \\
H3 & Attitude homophily - Kredibilitas & 3,869 & $0,000^{* * *}$ & Terbukti \\
H4 & Attitude homophily - Parasocial Interaction & 0,738 & 0,230 & Tidak Terbukti \\
H5 & Social Attractiveness - Parasocial Interaction & 5,279 & $0,000^{* * * *}$ & Terbukti \\
H6 & Kredibilitas - Niat Beli & 0,098 & 0,461 & Tidak Terbukti \\
H7 & Parasocial interaction - Niat Beli & 5,571 & $0,000^{* * * *}$ & Terbukti \\
\hline
\end{tabular}

Sumber: Output SmartPLS 3.3.3, data diolah

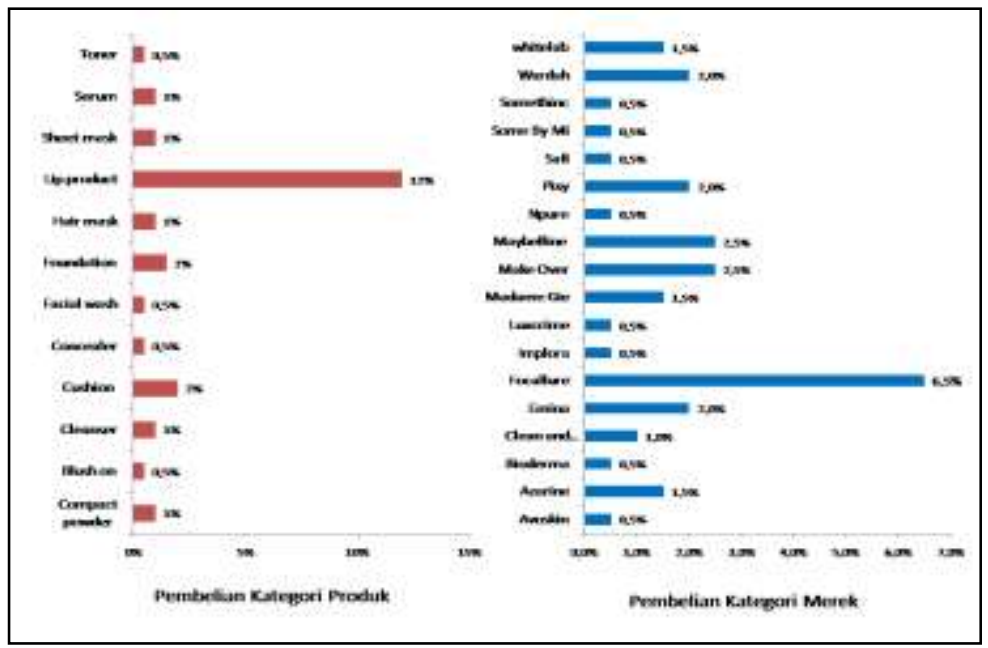

Sumber: Data diolah

Gambar 2. PEMBELIAN KATEGORI PRODUK DAN MEREK 


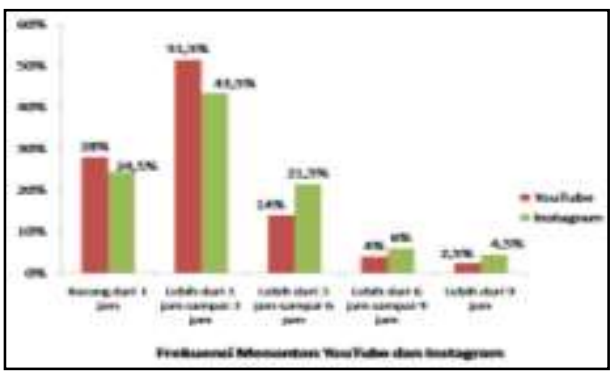

Sumber: Data diolah

\section{Gambar 3. FREKUENSI MENONTON YOUTUBE DAN INSTAGRAM}

\section{Pengaruh Physical Attractiveness terhadap Kredibilitas}

Physical attractiveness terbukti berpengaruh signifikan positif terhadap kredibilitas, artinya H1 didukung. Penelitian ini sejalan dengan Hong et al., (2019), Sokolova \& Kefi (2019), yang menyebutkan bahwa physical attractiveness berpengaruh signifikan positif terhadap kredibilitas. Responden perempuan yang berusia 17-35 tahun cenderung menonton beauty vlogger yang dapat menunjukkan penampilannya dengan baik dan menampilkan kesan produk yang sudah di-review sebelumnya. Physical atractiveness cenderung meningkatkan daya persuasi kepada penonton. Persuasi yang dilakukan oleh beauty vlogger membuat konsumen menonton review produk di YouTube dan Instagram 1-2 kali dalam satu bulan hingga lebih dari 6 kali dalam satu bulan dengan durasi menonton kurang dari 1 jam hingga lebih dari 9 jam setiap harinya. Karakteristik yang dimiliki beauty vlogger dalam mereview produk dengan detail dan kesesuaian produk akan membuat konsumen merasa yakin bahwa sumber tersebut kompeten. Dengan kata lain, physical atrractiveness dan kredibilitas dapat menjadi nilai jual bagi beauty vlogger. Pemasar dapat memanfaatkan physical atractiveness dan kredibilitas yang dimiliki beauty vlogger untuk bekerja sama dengan tujuan meningkatkan citra positif merek, meningkatkan brand awareness, dan meningkatkan penjualan. Hal tersebut dapat dilakukan pemasar dengan meminta beauty vlogger untuk mereview produk, iklan, atau menjadikan beauty vlogger tersebut sebagai brand ambassador.

\section{Pengaruh Physical Attractiveness terhadap Parasocial Interaction}

Physical attractiveness terbukti berpengaruh signifikan terhadap parasocial interaction, artinya $\mathrm{H} 2$ didukung. Hasil penelitian ini sejalan dengan penelitian (Lee \& Watkins, 2016; Liu et al., 2019; Putri \& Astuti, 2019). Hal tersebut menunjukkan bahwa semakin beauty vlogger tersebut dipandang sebagai seseorang yang memiliki physical attractiveness yang tinggi maka penonton akan semakin berkeinginan untuk berinteraksi dengan beauty vlogger tersebut.

Responden perempuan usia 17-35 tahun termasuk kategori dewasa muda. Mereka sangat tertarik dengan hal-hal yang baru dan berkeinginan untuk mencoba. Konsumen kosmetik berinteraksi dengan beauty vlogger melalui YouTube dan Instagram dengan mengikuti live atau berkomentar di akun media sosialnya. Beauty vlogger akan mereview produk yang sedang viral, review tersebut biasanya diminta oleh viewers media sosial. Apabila konten terkait produk menarik dan sedang viral, viewers akan tertarik untuk melihat dan menanyakan terkait produk tersebut. Viewers akan semakin penasaran apabila produk tersebut memberikan dampak positif kepada beauty vlogger. Hal tersebut semakin meningkatkan keinginan untuk berinteraksi. Pemasar harus memilih beauty vlogger yang memiliki physical attractiveness yang tinggi dan memiliki hubungan yang baik dengan penonton untuk memperkenalkan produknya kepada konsumen. Selain itu, pemasar produk kecantikan dapat menjalin kerja sama dengan beauty vlogger dengan mengadakan beauty class yang dihadiri oleh beauty vlogger agar individu dapat berinteraksi secara langsung.

\section{Pengaruh Attitude Homophily terhadap Kredibilitas}

Attitude homophily terbukti berpengaruh signifikan terhadap kredibilitas, artinya H3 didukung. Pengaruh dari attitude homophily terhadap kredibilitas menunjukkan positif, artinya apabila attitude homophily dari beauty vlogger semakin ditingkatkan maka kredibilitas beauty vlogger tersebut juga 
Lika Alda Septiani. Bagaimana Konsumen Kosmetik Memerhatikan Beauty Vlogger dan Pengaruhnya terhadap Niat Beli

akan meningkat. Hasil penelitian ini sejalan dengan Arviansyah et al., (2018), Sokolova \& Kefi (2019), Purnamaningsih \&Rizkalla (2020), yang menyatakan bahwa attitude homophily berpengaruh signifikan positif terhadap kredibilitas.

Attitude homophily merupakan faktor penentu kredibilitas karena mengacu pada persepsi kesamaan antara beauty vlogger dengan penonton. Tasya Farsaya selalu mereview produk yang aman untuk digunakan. Hal tersebut disampaikannya melalui channel YouTubenya yang mengatakan bahwa menghindari dan memerangi produk yang tidak aman untuk digunakan. Kesamaan penonton dengan beauty vlogger dalam menggunakan produk yang aman menjadikan penonton yakin bahwa beauty vlogger tersebut memiliki kredibilitas. Pemasar dapat meminta beauty vlogger tersebut untuk mereview produk dari perusahaannya, hal tersebut akan meningkatkan kesadaran merek dan pengetahuan konsumen bahwa produk dari perusahaan tersebut aman untuk digunakan.

\section{Pengaruh Attitude Homophily terhadap Parasocial Interaction}

Attitude homophily tidak terbukti berpengaruh signifikan terhadap parasocial interaction, artinya $\mathrm{H} 4$ tidak didukung. Hasil penelitian ini tidak sejalan dengan Lee \& Watkins (2016), Purnamaningsih \& Rizkalla (2020), dan Sokolova \& Kefi (2020). Attitude homophily dianggap pola hubungan berbasis pengaruh di media sosial. Attitude homophily tidak berpengaruh terhadap parasocial interaction karena interaksi viewers dengan beauty vlogger hanya berjalan satu arah yaitu hanya sekedar berkomentar dan membalas komentar. Kesamaan yang dimiliki tidak mendorong terjadinya interaksi ke arah yang lebih dalam seperti diskusi ringan mengenai produk tersebut. Pemasar produk kosmetik dapat mengadakan talkshow dengan beauty vlogger agar terjadi diskusi produk dari perusahaannya.

\section{Pengaruh Social Attractiveness terhadap Parasocial Interaction}

Social attractiveness terbukti berpengaruh signifikan terhadap parasocial interaction. Hal ini menunjukkan bahwa H5 didukung hasil penelitian ini. Hasil penelitian ini sejalan dengan Lee \& Watkins (2016), Arviansyah et al., (2018), Sokolova \& Kefi (2020). Social attractiveness mengacu pada kecenderung sesorang untuk memilih figur yang dapat dijadikan untuk bersosialisasi dan memilih mitra kerja. Hasil penelitian tersebut menunjukkan bahwa responden yang menonton beauty vlogger merasakan adanya persahabatan yang dirasakan. Viewers akan merasa senang apabila dapat bertemu langsung dengan beauty vlogger. Selain itu, para viewers juga saling berbalas komentar mengenai postingan beauty vlogger. Beauty vlogger Tasya Farasya juga membalas beberapa komentar dari veiwers YouTube dan Instagram. Veiwers yang komentarnya dibalas oleh beauty vlogger merasa mendapat apresiasi. Pemasar dapat memanfaatkan kedekatan tersebut untuk kebutuhan komersil dengan mengadakan kegiatan meet and greet sekaligus ajang promosi dan pengenalan produk yang relevan dengan beuaty vlogger.

\section{Pengaruh Kredibilitas terhadap Niat Beli}

Kredibilitas tidak terbukti berpengaruh signifikan terhadap niat beli, artinya H6 tidak didukung penelitian ini. Penelitian ini tidak sejalan dengan hasil dari Argyris et al., (2020), Nam \& Dan (2018), Reinikeinen et al., (2020), dan Sokolova \& Kefi (2020) yang menyatakan bahwa kredibilitas berpengaruh signifikan positif terhadap niat beli. Namun dalam penelitian lainnya, kredibilitas tidak berpengaruh signifikan positif terhadap niat beli (Lim et al., 2017).

Responden mengakui kurangnya kredibilitas beauty vlogger terhadap produk yang di-review. Alasan utama yaitu kurangnya pengetahuan dan keahlian beauty vlogger tentang produk tersebut. Beauty vlogger yang berada di luar bidang yang dikuasai dapat secara tidak langsung merusak citra yang dirasakan konsumen sehingga menyebabkan tidak adanya niat beli. Pemasar dari merek Avoskin, Azarine, Bioderma, Clean and Clear, Emina, Focallure, Implora, Luxcrime, Madame Gie, Make Over, Maybelline, Npure, Pixy, Safi, Some By Mi, Somethinc, Wardah, dan Whitelab harus memilih beauty vlogger yang memiliki kredibilitas, dapat menarik penonton yang ditargetkan dan dapat memikat penonton melalui pesan iklan yang mengesankan. Hal tersebut untuk meningkatkan niat beli produk dan mendapatkan keunggulan kompetitif di pasar.

\section{Pengaruh Parasocial Interaction terhadap Niat Beli}


Parasocial interaction terbukti berpengaruh signifikan positif terhadap niat beli, artinya $\mathrm{H} 7$ didukung. Hasil penenlitian ini sejalan dengan Sokolova \& Kefi (2020); Kim (2020), Purnamaningsih \& Rizkalla (2020). Konsumen kosmetik melakukan interaksi dengan beauty vlogger melalui kolom komentar YouTube dan Instagram. Contohnya, pada kolom komentar video berjudul battle cushion lokal tersengit Make Over vs Somethinc yang di posting di akun YouTube Tasya Farasya (https://youtu.be/1EJjR5Bb138), viewers menanyakan tentang shade produk kosmetik Somethinc dan Make Over yang digunakan oleh beauty vlogger. Kemudian, beauty vlogger tersebut membalas komentar tersebut untuk memberikan jawaban. Selain itu, beauty vlogger Tasya Farasya juga membalas komentar terkait foundation yang digunakan. Hal tersebut menunjukkan ketertarikan viewers terhadap produk yang digunakan.

Lebih lanjut, hasil penelitian menunjukkan bahwa setelah menonton review, konsumen akan tertarik membeli beberapa kategori produk kosmetik yaitu compact powder, blush on, cleanser, cushion, concealer, facial wash, foundation, hair mask, lip product, sheet mask, serum, dan toner. Merekmerek kosmetik yang dibeli konsumen setelah melihat review adalah Avoskin, Azarine, Bioderma, Clean and Clear, Emina, Focallure, Implora, Luxcrime, Madame Gie, Make Over, Maybelline, Npure, Pixy, Safi, Some By Mi, Somethinc, Wardah, dan Whitelab. Pemasar dari merek dapat menjalin kerja sama dengan beauty vlogger untuk mereview produk dari perusahaannya dan meningkatkan penjualan dengan mengadakan kegiatan penjualan yang dibawakan langsung oleh beauty vlogger tersebut.

\section{KESIMPULAN}

Melalui teknik analisis PLS-SEM dapat disimpulkan bahwa physical attractiveness dan attitude homophiliy berpengaruh signifikan terhadap kredibilitas. Selain itu, physical attractiveness dan social attractiveness berpengaruh signifikan terhadap parasocial interaction, tetapi attitude homophily tidak berpengaruh signifikan terhadap parasocial interaction. Kemudian parasocial interaction juga berpengaruh signifikan terhadap niat beli, sedangkan Kredibilitas tidak bepengaruh signifikan terhadap niat beli. Hasil penelitian ini diharapkan dapat menambah pengetahuan terkait pengaruh beauty vlogger terhadap niat beli kosmetik dan dapat dimanfaatkan oleh pemasar. Keterbatasan penelitian ini berfokus pada wanita, beauty vlogger Tasya Farasya dan hanya pada sektor kecantikan. Penelitian selanjutnya dapat diterapkan pada merek tertentu dan menambah variabel information involvement, building motive, dan dapat diterapkan pada influencer lain seperti food vlogger di YouTube. Selain itu, menarik untuk melihat lebih lanjut bagaimana interaksi antar viewers vlogger.

\section{DAFTAR PUSTAKA}

Agustiara, R., Okatini, M., \& Jumhur, A. A. (2019). Effect of Beauty Vlogger Testimonial (Review) on Consumer Interest (Viewers) on Cosmetic Products. Jurnal of Business Studies, 5(2), 149156. https://doi.org/http://dx.doi.org/10.32497/jobs.v5i2.1715

Ajzen, I., \& Fishbein, M. (2001). Understanding Attitudes and Predicting Social Behavior. Englewood Cliffs, NJ: Prentice Hall.

Apriliani, D., Arimbawa, I. G., \& Wulandari, A. (2020). How Youtube Beauty Vlogger Review, Self Congruity and Price Perception Influence Impulse Buying and the Impact On Repurchase Intention (Case Study at Teenager Users of Emina Cosmetics In Surabaya). Quantitative Economics and Management Studies, 1(1), 33-43. https://doi.org/10.35877/454ri.qems1175

Argyris, Y. A., Muqaddam, A., \& Miller, S. (2020). The effects of the visual presentation of an Influencer's Extroversion on perceived credibility and purchase intentions-moderated by personality matching with the audience. Journal of Retailing and Consumer Services, 59(1), 20-38. https://doi.org/10.1016/j.jretconser.2020.102347 
Lika Alda Septiani. Bagaimana Konsumen Kosmetik Memerhatikan Beauty Vlogger dan Pengaruhnya terhadap Niat Beli

Arviansyah, Dhaneswara, A. P., Hidayanto, A. N., \& Zhu, Y. Q. (2018). Vlogging: Trigger to impulse buying behaviors. Twenty-Second Pacific Asia Conference on Information Systems: Japan.

Berryman, R., \& Kavka, M. (2017). 'I Guess A Lot of People See Me as a Big Sister or a Friend': the role of intimacy in the celebrification of beauty vloggers. Journal of Gender Studies, 26(3), 307-320. https://doi.org/10.1080/09589236.2017.1288611

Bhattacherjee, A., \& Sanford, C. (2016). Influence Processes for Information Technology Acceptance: An Elaboration Likelihood Model1. MIS Quarterly, 30(4), 805-825. https://doi.org/10.2307/25148755

Briliana, V., \& Mursito, N. (2017). Exploring antecedents and consequences of Indonesian Muslim youths' attitude towards halal cosmetic products: A case study in Jakarta. Asia Pacific Management Review, 22(4), 176-184. https://doi.org/10.1016/j.apmrv.2017.07.012

Chakraborty, U. (2019). The impact of source credible online reviews on purchase intention: The mediating roles of brand equity dimensions. Journal of Research in Interactive Marketing, 13(2), 142-161. https://doi.org/10.1108/JRIM-06-2018-0080

Chen, J.-L., \& Dermawan, A. (2020). The Influence of YouTube Beauty Vloggers on Indonesian Consumers' Purchase Intention of Local Cosmetic Products. International Journal of Business and Management, 15(5), 100. https://doi.org/10.5539/ijbm.v15n5p100

Copeland, L. R., \& Zhao, L. (2020). Instagram and theory of reasoned action: US consumers influence of peers online and purchase intention. International Journal of Fashion Design, Technology and Education, 13(3), 265-279. https://doi.org/10.1080/17543266.2020.1783374

Dibble, J. L., Hartmann, T., \& Rosaen, S. F. (2016). Parasocial Interaction and Parasocial Relationship: Conceptual Clarification and a Critical Assessment of Measures. Human Communication Research, 42(1), 21-44. https://doi.org/10.1111/hcre.12063

Djafarova, E., \& Rushworth, C. (2017). Exploring the credibility of online celebrities' Instagram profiles in influencing the purchase decisions of young female users. Computers in Human Behavior, 68(1), 1-7. https://doi.org/10.1016/j.chb.2016.11.009

Egan, J. (2014). Marketing Communications (2nd ed.). London: SAGE Publications.

Engel, J. F., Blackwell, R. D., \& Miniard, P. W. (1995). Perilaku Konsumen (6th ed.). Jakarta: Binarupa.

Eyal, K., \& Rubin, A. M. (2010). Viewer Aggression and Homophily , Identification , and Parasocial Relationships With Television Characters Viewer Aggression and Homophily, With Television Characters. Journal of Broadcasting \& Electronic Media, 47(1), 77-98. https://doi.org/10.1207/s15506878jobem4701

Frederick, E. L., Lim, C. H., Clavio, G., \& Walsh, P. (2016). Why We Follow: An Examination of Parasocial Interaction and Fan Motivations for Following Athlete Archetypes on Twitter. International Journal of Sport Communication, 5(4), 481-502. https://doi.org/10.1123/ijsc.5.4.481

Freeman, B., \& Chapman, S. (2007). Is "YouTube" telling or selling you something? Tobacco content on the YouTube video-sharing website. Tobacco Control, 16(3), 207-210. https://doi.org/10.1136/tc.2007.020024

Hair, J. F., Hult, G. T. M., Ringle, C. M., \& Sarstedt, M. (2016). A Primer on Partial Least Squares 
Structural Equation Modeling (PLS-SEM) - Joseph F. Hair, Jr., G. Tomas M. Hult, Christian Ringle, Marko Sarstedt. In Sage.

Hestianingsih. (2019). Mengenal Jenis-jenis Influencer Berdasarkan Jumlah Followers. Retrieved February 5, 2021, from https://wolipop.detik.com/worklife/d-4526297/mengenal-jenis-jenisinfluencer-berdasarkan-jumlah-followers

Hong, S., Lee, H., \& Johnson, E. K. (2019). The face tells all: Testing the impact of physical attractiveness and social media information of spokesperson on message effectiveness during a crisis. Journal of Contingencies and Crisis Management, 27(3), 257-264. https://doi.org/10.1111/1468-5973.12250

instagram.com. (2021). Tasya Farasaya (@tasyafarasya) Instagram photos and videos. Retrieved February 28, 2021, from https://www.instagram.com/tasyafarasya/?hl=id

Jalilvand, M. R., \& Samiei, N. (2012). The effect of electronic word of mouth on brand image and purchase intention: An empirical study in the automobile industry in Iran. Marketing Intelligence and Planning, 30(4), 460-476. https://doi.org/10.1108/02634501211231946

Jerslev, A. (2016). In the time of the microcelebrity: Celebrification and the YouTuber Zoella. International Journal of Communication, 10, 5233-5251.

Kim, H. (2020). Unpacking Unboxing Video-Viewing Motivations: The Uses and Gratifications Perspective and the Mediating Role of Parasocial Interaction on Purchase Intent. Journal of Interactive Advertising, 20(3), 196-208. https://doi.org/10.1080/15252019.2020.1828202

Lee, J. E., \& Watkins, B. (2016). YouTube vloggers' influence on consumer luxury brand perceptions and intentions. Journal of Business Research, 69(12), 5753-5760. https://doi.org/10.1016/j.jbusres.2016.04.171

Lim, X. J., Radzol, A. R. bt M., Cheah, J.-H., \& Wong, M. W. (2017). The Impact of Social Media Influencers on Purchase Intention and the Mediation Effect of Customer Attitude. Asian Journal of Business Research, 7(2), 18-36. https://doi.org/10.14707/ajbr.170035

Liu, M. T., Liu, Y., \& Zhang, L. L. (2019). Vlog and brand evaluations: the influence of parasocial interaction. Asia Pacific Journal of Marketing and Logistics, 31(2), 419-436. https://doi.org/10.1108/APJML-01-2018-0021

Lova, C. (2020). Disebut sebagai Beauty Vlogger Termahal, Tasya Farasya: Follower Terbanyak. Retrieved January 4, 2020, from https://today.line.me/id/v2/article/Disebut+sebagai+Beauty+Vlogger+Termahal+Tasya+Farasy a+Follower+Terbanyak-2qJy9N

Lutfia. (2021). 5 Keahlian yang Dimiliki Content Creator. Retrieved June 20, 2021, from https://kumparan.com/lutfia-1600257725225904134/5-keahlian-yang-dimiliki-content-creator$1 \mathrm{vNh} 4 \mathrm{Zjy} 9 \mathrm{pu}$

Nam, L. G., \& Dan, H. T. (2018). Impact of social media Influencer marketing on consumer at Ho Chi Minh City. The International Journal of Social Sciences and Humanities Invention, 5(5), 4710-4714. https://doi.org/10.18535/ijsshi/v5i5.10

Nandagiri, V., \& Philip, L. (2018). The Impact of Influencers from Instagram and YouTube on their Followers. International Journal of Multidisciplinary Research and Modern Education, 4(1), 61-65. Retrieved from https://www.researchgate.net/profile/VaibhaviNandagiri/publication/323996049_The_impact_of_influencers_from_Instagram_and_YouTube 
Lika Alda Septiani. Bagaimana Konsumen Kosmetik Memerhatikan Beauty Vlogger dan Pengaruhnya terhadap Niat Beli

_on_their_followers/links/5ab77efc0f7e9b68ef50950f/The-impact-of-influencers-fromInstagram-and-YouTube-on-their-followers.pd

napoleoncat.com. (2021). Instagram users in Indonesia. Retrieved April 28, 2021, from https://napoleoncat.com/stats/instagram-users-in-indonesia/2021/01

Nasuha, W. (2020). Tasya Farasya Hingga Abel Cantika, Ini Penghasilan Bulanan Beauty Vlogger Terhits di Indonesia, Nominalnya Fantastis! Retrieved January 4, 2020, from https://herstory.co.id/read2392/tasya-farasya-hingga-abel-cantika-ini-penghasilan-bulananbeauty-vlogger-terhits-di-indonesia-nominalnya-fantastis

Pick, M. (2020). Psychological ownership in social media influencer marketing. European Business Review, 33(1), 111-127. https://doi.org/10.1108/EBR-08-2019-0165

Purnamaningsih, P., \& Rizkalla, N. (2020). The Role of Parasocial Interaction on Consumers' Intention to Purchase Beauty Products. Journal of Retailing and Consumer Services, 6(12), 1327. Retrieved from https://ssrn.com/abstract=3701912

Putri, I. T., \& Astuti, R. D. (2019). Comparative analysis of youtuber and celebgram in developing consumer brand perceptions and intentions to buy luxury brand cosmetics. ASEAN Marketing Journal, 11(2). Retrieved from http://journal.ui.ac.id/index.php/amj

Rahmi, Y., Sekarasih, L., \& Sjabadhyni, B. (2017). The Influence of Beauty Vlog on Perceived Source Credibility and Purchase Intention. Makara Human Behavior Studies in Asia, 21(1), 13. https://doi.org/10.7454/mssh.v21i1.3496

Ramadanty, S., Muqarrabin, A. M., Nita, W. A., \& Syafganti, I. (2020). Examining the effect of persuasive message of beauty vloggers on information acceptance of ewom and purchase intention: The study of consumers of beauty products in Jabodetabek, Indonesia. Pertanika Journal of Social Sciences and Humanities, 28(2), 763-775.

Razak, N. I. A., \& Zulkifly, M. I. (2020). The impacts of food vlog attributes on para-social interaction and customers' response behaviours. Journal of Tourism, Hospitality and Culinary Arts, 12(1), 435-445. Retrieved from https://www.jthca.org/

Reinikainen, H., Munnukka, J., Maity, D., \& Luoma-aho, V. (2020). 'You really are a great big sister'-parasocial relationships, credibility, and the moderating role of audience comments in influencer marketing. Journal of Marketing Management, 36(3-4), 279-298. https://doi.org/10.1080/0267257X.2019.1708781

Safira, A., Putri, D. W., \& Wattimena, G. H. (2019). Self presentation beauty influencer Abel Cantika via Youtube. Profetik Jurnal Komunikasi, 12(1), 30-45. https://doi.org/https://doi.org/10.14421/pjk.v12i1.1583

Sendari, A. A. (2019). Instagram adalah paltform berbagi foto dan video, ini deretan fitur canggihnya. Retrieved February 3, 2021, from https://www.liputan6.com/tekno/read/3906736/instagramadalah-platform-berbagi-foto-dan-video-ini-deretan-fitur-canggihnya

Sokolova, K., \& Kefi, H. (2020). Instagram and YouTube bloggers promote it, why should I buy? How credibility and parasocial interaction influence purchase intentions. Journal of Retailing and Consumer Services, 53. https://doi.org/10.1016/j.jretconser.2019.01.011

Tesalonika. (2020). Jumlah Penggguna Unik Youtube di Indonesia Capai 93 Juta. Retrieved January 4, 2020, from https://www.tek.id/tek/jumlah-pengguna-unik-youtube-di-indonesia-capai-93juta-b1ZT79iPE 
Tysara, L. (2021). 7 Jenis-jenis Video di YouTube , Lengkap Cara Membuat Channel dan Upload. Retrieved June 19, 2021, from https://hot.liputan6.com/read/4584087/7-jenis-jenis-video-diyoutube-lengkap-cara-membuat-channel-dan-upload

Veirman, M. De, Cauberghe, V., \& Hudders, L. (2017). Marketing through instagram influencers: The impact of number of followers and product divergence on brand attitude. International Journal of Advertising, 36(5), 798-828. https://doi.org/10.1080/02650487.2017.1348035

wearesocial.com. (2020). Indonesia Digital Report 2020. Retrieved November 16, 2020, from https://datareportal.com/reports/digital-2020-global-digital-overview

Xiao, M., Wang, R., \& Chan-Olmsted, S. (2018). Factors affecting YouTube influencer marketing credibility: a heuristic-systematic model. Journal of Media Business Studies, 15(3), 188-213. https://doi.org/10.1080/16522354.2018.1501146

Zhou, L., \& Wang, T. (2014). Social media: A new vehicle for city marketing in china. Cities, 37(1), 27-32. https://doi.org/10.1016/j.cities.2013.11.006 